\title{
The context of gene expression regulation
}

\section{Johan H. Gibcus and Job Dekker*}

\author{
Address: Program in Systems Biology; Program in Gene Function and Expression, University of Massachusetts Medical School, \\ Worcester, MA, USA \\ * Corresponding author: Job Dekker (Job.Dekker@umassmed.edu) \\ FI000 Biology Reports 2012, 4:8 (doi:10.34I0/B4-8) \\ This is an open-access article distributed under the terms of the Creative Commons Attribution-Non Commercial License \\ (http://creativecommons.org/licenses/by-nc/3.0/legalcode), which permits unrestricted use, distribution, and reproduction in any medium, \\ provided the original work is properly cited. You may not use this work for commercial purposes. \\ The electronic version of this article is the complete one and can be found at: http://fl000.com/reports/b/4/8
}

\begin{abstract}
Recent advances in sequencing technologies have uncovered a world of RNAs that do not code for proteins, known as non-protein coding RNAs, that play important roles in gene regulation. Along with histone modifications and transcription factors, non-coding RNA is part of a layer of transcriptional control on top of the DNA code. This layer of components and their interactions specifically enables (or disables) the modulation of three-dimensional folding of chromatin to create a context for transcriptional regulation that underlies cell-specific transcription. In this perspective, we propose a structural and functional hierarchy, in which the DNA code, proteins and non-coding RNAs act as context creators to fold chromosomes and regulate genes.
\end{abstract}

\section{Introduction}

Transcriptional regulation of eukaryotic genes has classically been viewed as the interaction of elements in the immediate vicinity of the transcription start site (promoters) with upstream elements (enhancers) [1,2]. Mutations in conserved upstream promoter DNA sequences affect gene expression directly $[3,4]$. However, transcriptional regulation is not only determined by DNA sequence but involves additional layers of control that include nucleosome positioning, DNA binding regulatory proteins such as transcription factors, histone modifications and non-coding RNA [5-7]. Moreover, the development of high throughput chromosome conformation capture techniques [8] has shown that the three-dimensional organization of genes and upstream elements affects transcriptional activity [9-11]. Here, we present how the combination of these factors can provide a "context" for the regulation of gene expression.

\section{Putting the genome into context The concept of context}

Gene expression regulation in eukaryotes includes interactions between promoters and enhancers, but our understanding of the mechanisms that drive these interactions, or that determine their specificity, is far from complete. At the basis of transcription lies the DNA code that directly determines the composition and location of DNA elements and provides specific recognition sites for DNA binding proteins. The binding of transcription factors and recruitment of complexes that modify histones create an environment that allows for element interaction and initiation of gene transcription. However, predicting the location of promoters and enhancers based solely on histone modifications and transcription factor binding relies on complicated models that are still suboptimal [12-14]. Moreover, recent findings on the involvement of non-coding RNA in transcriptional regulation further imply a more complicated reality $[15,16]$. Is there a combination of histone modifications which is sufficient to predict the position of regulatory elements? Are specific non-coding RNA transcripts involved in recruiting proteins to regulatory elements?

It is now highly debated whether chromatin modifications comprise a "code" similar to DNA (reviewed by Henikoff and Shilatifard [17]). The crosstalk between histones, transcription factors and non-coding RNA suggest that they interact to form a highly interwoven level of organization [16]. In the context model, transcriptional 
regulation is subdivided into three levels of interactions: the DNA level, the local chromatin level, and the threedimensional folding of the genome. The first level, the DNA code, forms an interaction platform by providing protein binding sites for transcription factors that, together with non-coding RNAs and histone modifications, form the next layer of gene regulation. This layer of interactions enables specific long-range interactions that result in a three-dimensional folding of the chromatin. This higher order organization provides transcriptional context that can either facilitate or block the initiation of transcription (Figure 1). Importantly, changes at any level are not necessarily unidirectional. Compaction of higher order structures, for example, will influence the accessibility of DNA and binding of transcription factors, providing a likely feedback mechanism. Below we describe each of the layers of context in more detail.

\section{Level I: the DNA code}

The binding of (core) transcription factors critically depends on the recognition of specific DNA sequences, known as DNA motifs. High throughput techniques,

Figure I. The context model
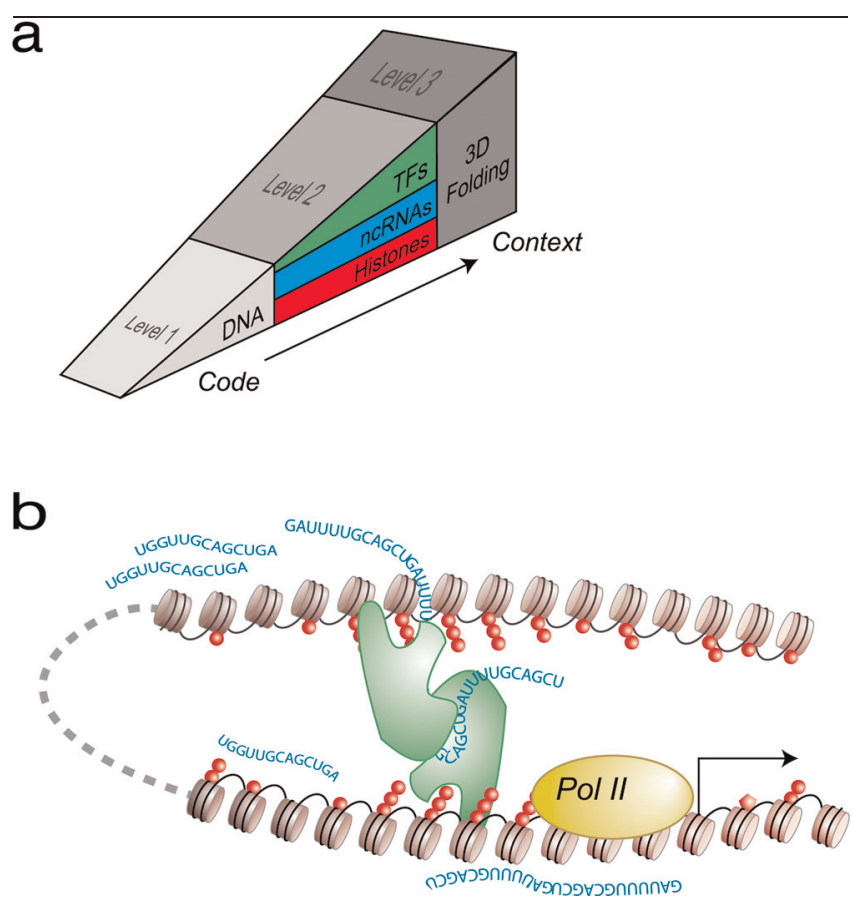

(a) The context model of gene expression consists of three layers of regulation, each representing a level of interactions that allows the transition from code to context. (b) DNA, the first layer, interacts with non-coding RNA (arbitrary sequence in blue), TFs (green) and histone modifications (red). The third layer is the resulting 3D folding (dotted line), which creates the final context for gene transcription. Abbreviations: ncRNA, non-coding RNA; TF, transcription factor; 3D, three-dimensional. such as ChIP-seq and enhanced yeast one-hybrid, which visualizes the interaction of a transcription factor with a bait DNA sequence, are now employed to uncover transcription factor-DNA and DNA-transcription factor interactions, respectively $[18,19]$. Such studies show that transcription factor-binding events are abundant and can occur at large genomic distances from genes. Similarly, conserved non-coding sequences can be found throughout the genome. Their conservation implies that they have an important function - they may affect the binding affinity of factors, or encode non-coding RNAs [20,21]. Interestingly, deletion of these sequences with unknown function can influence gene expression of genes located hundreds of Kb away, implying that long-range looping of DNA brings the sequences into contact with the genes they regulate [22].

\section{Level 2: context creators}

This level of interactions involves histone positioning and modifications, repertoires of transcription factors and non-coding RNA and the interplay between them. This level is perhaps the most complex, and it has become the center of attention in recent years.

Although nucleosome positioning, histone modifications, non-coding RNA and transcription factor binding are useful descriptors for genomic elements, they do not seem to define regulatory elements by themselves [17]. Histone modifications have been used to classify upstream regions as promoters (i.e. H3K4me3) and enhancers (i.e. H3K4me1, H3K27ac) [13], but this may not reflect the complete picture. Recent developments in DNA sequencing have led to the appreciation of the importance of noncoding RNA as a regulatory component in the genome $[15,23,24]$. Although the extent of non-coding RNA involvement is still debated [25], more and more examples of the involvement of non-coding RNA in transcriptional regulation appear in the current literature. Both long and short non-coding RNAs have been identified at regulatory elements $[26,27]$. Their function is still mostly unknown, and their nomenclature is purely descriptive, based on their site of occurrence (e.g. PASR for Promoter-Associated Short RNA or eRNA for enhancerRNA) $[23,28]$. It is possible that non-coding RNA can act as a fast and flexible intermediate to recruit histonemodifying complexes to DNA elements [29-32]. Several reports on long non-coding RNA have shown their involvement in chromatin remodeling, affecting differentiation and disease [33] (reviewed by Huarte and Rinn [34] and Hung and Chang [35]). Long non-coding RNAs have also been found to be involved in transcriptional repression via polycomb proteins, which are known to maintain cell identity by repressing developmental regulators in certain cell types $[15,16,31]$. Although long 
non-coding RNA are now widely studied, small non-coding RNA and antisense RNA have also been implicated in polycomb-mediated transcriptional gene silencing [36-38]. The combinatorial complexity at this level of chromatin regulation and structure is further modulated by feedback and feedforward signals between histone modifications, non-coding RNA and transcription factors.

\section{Level 3: context}

The three-dimensional folding of DNA is the final context that allows for gene transcription to initiate. The folding of DNA into higher order structures is not a random event, and it has long been thought to affect gene transcription [39-42]. At the nuclear level, chromosomes occupy specific nuclear territories (reviewed by Cremer and Cremer [43]). Chromatin interactions within and between broad zones of chromosomes lead to nuclear compartments where active genes tend to co-locate, near the center of the nucleus, and inactive genes cluster near the nuclear periphery. This indicates a strong correlation, though not necessarily causation, between nuclear positioning and gene activity (reviewed by Geyer et al. [44]). At the finest scale, precise DNA folding or "looping" interactions between gene promoters and their distal regulatory elements can be found. DNA looping (level 3) is guided by long-range interactions between DNA sequence elements (level 1), which can be mediated by interacting context creators (level 2). An illustration of the interplay between multiple levels of regulation that leads to a context for gene expression can be found in the regulation of the HOXA locus. Here, chromosomal looping brings the non-coding RNA HOTTIP in close proximity to HOXA genes. HOTTIP recruits the histone 3 lysine 4 modifying complex MLL by binding to WDR5, targeting this complex to the HOXA locus. As a result, HOTTIP controls HOXA gene expression by bridging higher-order chromosomal looping and chromatin modifications [26]. This exemplifies how context provides an environment for communication between regulatory elements in three-dimensional space, leading to either activation or repression of gene transcription.

\section{Summary}

Recent technical advances in DNA sequencing have enabled genome-wide analysis at each of the three levels: (1) genome sequencing to identify conserved regulatory elements; (2) ChIP-seq [45], DeepCAGE [46], RNA-seq [47], NET-seq [48], ChiRP [49] and CHART [50] to identify chromatin modification, transcription factor binding and (non-coding) RNA expression and localization; and (3) 3C combined with deep sequencing (e.g. Hi-C and 3-seq) $[8,51,52]$ to probe three-dimensional folding of the genome. Combined, these tools allow an integrated systems approach towards a more complete understanding of the context in which the genome is regulated.

\section{Competing interests}

The authors declare they have no competing interests.

\section{Acknowledgements}

Supported by a Rubicon grant from the Netherlands Organisation for Scientific Research and a Dutch Cancer Society Fellowship to Johan H. Gibcus. Supported by grants from the National Institutes of Health, National Human Genome Research Institute (HG003143 and HG003143-06S1), and a W.M Keck Foundation distinguished young scholar in medical research grant to Job Dekker.

\section{References}

I. Mitchell PJ, Tjian R: Transcriptional regulation in mammalian cells by sequence-specific DNA binding proteins. Science 1989 , 245:37|-8.

2. Ren X, Siegel R, Kim U, Roeder RG: Direct interactions of OCA-B and TFII-I regulate immunoglobulin heavy-chain gene transcription by facilitating enhancer-promoter communication. Mol. Cell 20I I, 42:342-55.

3. Heintzman ND, Ren B: The gateway to transcription: identifying, characterizing and understanding promoters in the eukaryotic genome. Cell. Mol. Life Sci 2007, 64:386-400.

4. Stefano JE, Ackerson JW, Gralla JD: Alterations in two conserved regions of promoter sequence lead to altered rates of polymerase binding and levels of gene expression. Nucleic Acids Res 1980, 8:2709-23.

5. Venters BJ, Pugh BF: How eukaryotic genes are transcribed. Crit. Rev. Biochem. Mol. Biol 2009, 44:| |7-4|.

6. Mercer TR, Dinger ME, Mattick JS: Long non-coding RNAs: insights into functions. Nat. Rev. Genet 2009, 10:155-9.

7. Goodrich JA, Kugel JF: Non-coding-RNA regulators of RNA polymerase II transcription. Nat. Rev. Mol. Cell Biol 2006, 7:6I2-6.

8. van Steensel B, Dekker J: Genomics tools for unraveling chromosome architecture. Nat. Biotechnol 2010, 28:1089-95.

9. Tolhuis B, Palstra RJ, Splinter E, Grosveld F, de Laat W: Looping and interaction between hypersensitive sites in the active betaglobin locus. Mol. Cell 2002, I0:|453-65.

FI000 Factor 12

Evaluated by David Schatz 13 Jan 2003, Michael Meisterernst 17 Mar 2003

10. Vernimmen D, Marques-Kranc F, Sharpe JA, Sloane-Stanley JA, Wood WG, Wallace HAC, Smith AJH, Higgs DR: Chromosome looping at the human alpha-globin locus is mediated via the major upstream regulatory element (HS -40). Blood 2009, I | 4:4253-60.

II. Baù D, Sanyal A, Lajoie BR, Capriotti E, Byron M, Lawrence JB, Dekker J, Marti-Renom MA: The three-dimensional folding of the $\alpha$-globin gene domain reveals formation of chromatin globules. Nat. Struct. Mol. Biol 201 I, I 8:107-I4.

FI000 Factor 6

Evaluated by John Stamatoyannopoulos 16 May 201 I

12. Heintzman ND, Hon GC, Hawkins RD, Kheradpour P, Stark A, Harp LF, Ye Z, Lee LK, Stuart RK, Ching CW, Ching KA, AntosiewiczBourget JE, Liu H, Zhang X, Green RD, Lobanenkov VV, Stewart R, Thomson JA, Crawford GE, Kellis M, Ren B: Histone modifications 
at human enhancers reflect global cell-type-specific gene expression. Nature 2009, 459:108-12.

FI000 Factor 16

Evaluated by Brad Bernstein and Alon Goren 03 Apr 2009, ChengMing Chiang 06 Apr 2009, Stephen Schwartz 20 May 2009, Michael Cole and Jason Wright 15 Jul 2009

13. Heintzman ND, Stuart RK, Hon G, Fu Y, Ching CW, Hawkins RD, Barrera LO, van Calcar S, Qu C, Ching KA, Wang W, Weng Z, Green RD, Crawford GE, Ren B: Distinct and predictive chromatin signatures of transcriptional promoters and enhancers in the human genome. Nat. Genet 2007, 39:31 I-8.

FI000 Factor 6

Evaluated by Kenneth Zaret II Apr 2007

14. Ernst J, Kheradpour P, Mikkelsen TS, Shoresh N, Ward LD, Epstein CB, Zhang $X$, Wang L, Issner $R$, Coyne M, Ku M, Durham $T$, Kellis $M$, Bernstein BE: Mapping and analysis of chromatin state dynamics in nine human cell types. Nature 20II, 473:43-9.

FI000 Factor 6

Evaluated by I King Jordan and Ahsan Huda 21 Oct 201 I

15. Khalil AM, Guttman M, Huarte M, Garber M, Raj A, Rivea Morales D, Thomas K, Presser A, Bernstein BE, van Oudenaarden A, Regev A, Lander ES, Rinn JL: Many human large intergenic noncoding RNAs associate with chromatin-modifying complexes and affect gene expression. Proc. Natl. Acad. Sci. U.S.A 2009, 106: I |667-72.

16. Yang L, Lin C, Liu W, Zhang J, Ohgi KA, Grinstein JD, Dorrestein PC, Rosenfeld MG: ncRNA- and Pc2 methylation-dependent gene relocation between nuclear structures mediates gene activation programs. Cell 20II, 147:773-88.

17. Henikoff S, Shilatifard A: Histone modification: cause or cog? Trends Genet 201 I, 27:389-96.

18. Johnson DS, Mortazavi A, Myers RM, Wold B: Genome-wide mapping of in vivo protein-DNA interactions. Science 2007, 3 | 6: | $497-502$

\section{FI000 Factor 18}

Evaluated by Jim Maher 06 Jun 2007, John Jaenike 21 Jun 2007, Deyou Zheng 29 Jun 2007, Ulf Pettersson 17 Jul 2007, Gabriele Varani 14 Aug 2007, Magdalena Zernicka-Goetz I5 Jan 2008

19. Reece-Hoyes JS, Barutcu AR, McCord RP, Jeong JS, Jiang L, MacWilliams A, Yang X, Salehi-Ashtiani K, Hill DE, Blackshaw S, Zhu H, Dekker J, Walhout AJM: Yeast one-hybrid assays for gene-centered human gene regulatory network mapping. Nat. Methods 201 I, 8:1050-2.

20. Prabhakar S, Visel A, Akiyama JA, Shoukry M, Lewis KD, Holt A, Plajzer-Frick I, Morrison H, Fitzpatrick DR, Afzal V, Pennacchio LA, Rubin EM, Noonan JP: Human-specific gain of function in a developmental enhancer. Science 2008, 32 I: | 346-50.

FI000 Factor 8

Evaluated by Ulf Pettersson 29 Sep 2008

21. Feng J, Bi C, Clark BS, Mady R, Shah P, Kohtz JD: The Evf-2 noncoding RNA is transcribed from the Dlx-5/6 ultraconserved region and functions as a Dlx-2 transcriptional coactivator. Genes Dev 2006, 20:|470-84.

FI000 Factor 8

Evaluated by Andrew D Sharrocks 19 Jun 2006

22. D'haene B, Attanasio C, Beysen D, Dostie J, Lemire E, Bouchard P, Field M, Jones K, Lorenz B, Menten B, Buysse K, Pattyn F, Friedli M, Ucla C, Rossier C, Wyss C, Speleman F, de Paepe A, Dekker J, Antonarakis SE, de Baere E: Disease-causing $\mathbf{7 . 4}$ kb cis-regulatory deletion disrupting conserved non-coding sequences and their interaction with the FOXL2 promotor: implications for mutation screening. PLoS Genet 2009, 5:el000522.

23. Kapranov P, Cheng J, Dike S, Nix DA, Duttagupta R, Willingham AT, Stadler PF, Hertel J, Hackermüller J, Hofacker IL, Bell I, Cheung E,
Drenkow J, Dumais E, Patel S, Helt G, Ganesh M, Ghosh S, Piccolboni A, Sementchenko V, Tammana H, Gingeras TR: RNA maps reveal new RNA classes and a possible function for pervasive transcription. Science 2007, 3 I 6: |484-8.

FI000 Factor 14

Evaluated by Ulf Pettersson 24 Jul 2007, Albert La Spada 25 Jul 2007, Sabine Müller OI Oct 2007, Gabriele Varani 3I Oct 2007

24. Mattick JS: Non-coding RNAs: the architects of eukaryotic complexity. EMBO Rep 200I, 2:986-9I.

FI000 Factor 8

Evaluated by Alain Ghysen 18 Dec 2001

25. van Bakel H, Nislow C, Blencowe BJ, Hughes TR: Most “dark matter" transcripts are associated with known genes. PLOS Biol 2010, 8:el00037I.

FI000 Factor 15

Evaluated by Daniel Reines 01 Jun 2010, Andre Nantel and Adnane Sellam 03 Jun 2010, Stuart Macdonald 02 Sep 2010, Adam Siepel 25 Oct 2010

26. Wang KC, Yang YW, Liu B, Sanyal A, Corces-Zimmerman R, Chen Y, Lajoie BR, Protacio A, Flynn RA, Gupta RA, Wysocka J, Lei M, Dekker J, Helms JA, Chang HY: A long noncoding RNA maintains active chromatin to coordinate homeotic gene expression. Nature 201 I, 472:120-4.

FI000 Factor 17

Evaluated by Pamela Geyer 13 Apr 201 I, Leonie Ringrose 09 May 201I, lannis Aifantis and Panagiotis Ntziachristos 17 May 201 I, W. Lee Kraus 20 May 2011

27. Ørom UA, Derrien $T$, Beringer $M$, Gumireddy $K$, Gardini A, Bussotti G, Lai F, Zytnicki M, Notredame C, Huang Q, Guigo R, Shiekhattar R: Long noncoding RNAs with enhancer-like function in human cells. Cell 2010, I43:46-58.

FI000 Factor 19

Evaluated by Nadia Rosenthal and Enrique Lara-Pezzi 18 Oct 2010, Herbert Steinbeisser 22 Oct 2010, John Abrams 26 Oct 2010, Frederic Allain, Antoine Clery and Dominik Theler 27 Oct 2010, Leonie Ringrose 18 Nov 2010

28. Kim T, Hemberg M, Gray JM, Costa AM, Bear DM, Wu J, Harmin DA Laptewicz M, Barbara-Haley K, Kuersten S, MarkenscoffPapadimitriou E, Kuhl D, Bito H, Worley PF, Kreiman G, Greenberg ME: Widespread transcription at neuronal activity-regulated enhancers. Nature 2010, 465:182-7.

FI000 Factor 8

Evaluated by Andrew D Sharrocks 20 May 2010

29. Nagano T, Fraser P: No-nonsense functions for long noncoding RNAs. Cell 201 I, I45:178-81.

30. Wang KC, Chang HY: Molecular mechanisms of long noncoding RNAs. Mol. Cell 20II, 43:904-I4.

31. Zhao J, Ohsumi TK, Kung JT, Ogawa Y, Grau DJ, Sarma K, Song JJ, Kingston RE, Borowsky M, Lee JT: Genome-wide identification of polycomb-associated RNAs by RIP-seq. Mol. Cell 2010, 40:939-53.

FI000 Factor 8

Evaluated by Michael Cole and Mandeep Kaur 07 Mar 20I I

32. Jeon $Y$, Lee JT: $Y Y I$ tethers $X i s t ~ R N A$ to the inactive $\mathbf{X}$ nucleation center. Cell 20II, I46:II9-33.

FI000 Factor 8

Evaluated by Leonie Ringrose 01 Aug 201 I

33. Gupta RA, Shah N, Wang KC, Kim J, Horlings HM, Wong DJ, Tsai M, Hung T, Argani P, Rinn JL, Wang Y, Brzoska P, Kong B, Li R, West RB, van de Vijver MJ, Sukumar S, Chang HY: Long non-coding RNA HOTAIR reprograms chromatin state to promote cancer metastasis. Nature 2010, 464:107|-6. 
34. Huarte M, Rinn JL: Large non-coding RNAs: missing links in cancer? Hum. Mol. Genet 2010, 19:RI52-6I.

35. Hung $T$, Chang HY: Long noncoding RNA in genome regulation: prospects and mechanisms. RNA Biol, 7:582-5.

36. Kanhere A, Viiri K, Araújo CC, Rasaiyaah J, Bouwman RD, Whyte WA, Pereira CF, Brookes E, Walker K, Bell GW, Pombo A Fisher AG, Young RA, Jenner RG: Short RNAs are transcribed from repressed polycomb target genes and interact with polycomb repressive complex-2. Mol. Cell 20I0, 38:675-88.

FI000 Factor 8

Evaluated by Kenneth Zaret 24 Jun 2010

37. Janowski BA, Huffman KE, Schwartz JC, Ram R, Nordsell $R$, Shames DS, Minna JD, Corey DR: Involvement of AGOI and AGO2 in mammalian transcriptional silencing. Nat. Struct. Mol. Biol 2006, I3:787-92.

38. Kim DH, Villeneuve LM, Morris KV, Rossi J]: Argonaute-I directs siRNA-mediated transcriptional gene silencing in human cells. Nat. Struct. Mol. Biol 2006, 13:793-7.

\section{FI000 Factor 8}

Evaluated by Kuan-Teh Jeang I4 Dec 2006

39. Horn PJ, Peterson CL: Molecular biology. Chromatin higher order folding-wrapping up transcription. Science 2002, 297: I824-7.

40. Sexton $T$, Schober $H$, Fraser $P$, Gasser SM: Gene regulation through nuclear organization. Nat. Struct. Mol. Biol 2007, I4: 1049-55.

41. Lanctôt C, Cheutin T, Cremer M, Cavalli G, Cremer T: Dynamic genome architecture in the nuclear space: regulation of gene expression in three dimensions. Nat. Rev. Genet 2007, 8:104-15.

42. Dekker J: Gene regulation in the third dimension. Science 2008, 319:1793-4.

43. Cremer T, Cremer M: Chromosome territories. Cold Spring Harb Perspect Biol 2010, 2:a003889.

44. Geyer PK, Vitalini MW, Wallrath LL: Nuclear organization: taking a position on gene expression. Curr. Opin. Cell Biol 20I I, 23:354-9.

45. Robertson G, Hirst M, Bainbridge M, Bilenky M, Zhao Y, Zeng T, Euskirchen G, Bernier B, Varhol R, Delaney A, Thiessen N, Griffith OL, He A, Marra M, Snyder M, Jones S: Genome-wide profiles of STATI DNA association using chromatin immunoprecipitation and massively parallel sequencing. Nat. Methods 2007, 4:65I-7.
46. Valen E, Pascarella G, Chalk A, Maeda N, Kojima M, Kawazu C, Murata M, Nishiyori H, Lazarevic D, Motti D, Marstrand TT, Tang ME, Zhao X, Krogh A, Winther O, Arakawa T, Kawai J, Wells C, Daub C, Harbers M, Hayashizaki Y, Gustincich S, Sandelin A, Carninci P: Genome-wide detection and analysis of hippocampus core promoters using DeepCAGE. Genome Res 2009, 19:255-65.

47. Mortazavi A, Williams BA, McCue K, Schaeffer L, Wold B: Mapping and quantifying mammalian transcriptomes by RNA-Seq. Nat Methods 2008, 5:621-8.

48. Churchman LS, Weissman JS: Nascent transcript sequencing visualizes transcription at nucleotide resolution. Nature 2011 , 469:368-73.

FI000 Factor 9

Evaluated by Tony Weil 03 Feb 20II, Anuj Kumar and Cole Johnson II Feb 20II

49. Chu C, Qu K, Zhong FL, Artandi SE, Chang HY: Genomic maps of long noncoding RNA occupancy reveal principles of RNAchromatin interactions. Mol. Cell 20I I, 44:667-78.

FI000 Factor 9

Evaluated by Hongjun Song and Junjie Guo 04 Nov 20II, Anindya Dutta and Neerja Karnani I3 Dec 20II

50. Simon MD, Wang $\mathrm{Cl}$, Kharchenko PV, West JA, Chapman BA, Alekseyenko AA, Borowsky ML, Kuroda MI, Kingston RE: The genomic binding sites of a noncoding RNA. Proc. Natl. Acad. Sci. U.S.A 20II, 108:20497-502.

5I. Lieberman-Aiden E, van Berkum NL, Williams L, Imakaev M, Ragoczy T, Telling A, Amit I, Lajoie BR, Sabo PJ, Dorschner MO, Sandstrom R, Bernstein B, Bender MA, Groudine M, Gnirke A, Stamatoyannopoulos J, Mirny LA, Lander ES, Dekker J: Comprehensive mapping of long-range interactions reveals folding principles of the human genome. Science 2009, 326:289-93.

FI000 Factor 22

Evaluated by Tom Tullius and Stephen Parker 28 Oct 2009, Tamar Schlick and Christian Laing 29 Oct 2009, Lloyd Smith 08 Dec 2009, Dean Jackson II Dec 2009, Thomas Ried 14 Dec 2009, Kenneth Zaret 19 Jan 2010, lan Dunham 31 Mar 2010, Greg Crawford, Nathan Sheffield and John Mayfield 09 Apr 2010

52. Soler E, Andrieu-Soler C, de Boer E, Bryne JC, Thongjuea S, Stadhouders R, Palstra R, Stevens M, Kockx C, van ljcken W, Hou J, Steinhoff C, Rijkers E, Lenhard B, Grosveld F: The genome-wide dynamics of the binding of LdbI complexes during erythroid differentiation. Genes Dev 2010, 24:277-89. 